\title{
THE PARASITE AND THE WIDOW
}

\author{
A way of life.
}

\section{BY JEREMY M. GOTTWIG}

$\mathrm{T}$ he taxi driver tossed Shelii's bags through the gate. "I've got a long flight back," he grumbled. "A long flight." He closed the hatch. The taxi nudged itself away from the small habitat. It arced back towards the peridot planet of Caldera: Shelii's home for 61 years.

She felt lonely. It hurt to leave.

The taxi driver hadn't permitted a lick of conversation that didn't involve his own complaints. Shelii had wanted to talk about her life and experiences as the only Earth human among a collective of worion expats. She wanted to ramble on about her husband, her other lovers, and her husband's other lovers. She wanted to ruminate about their increased solitude as the collective peeled away. She wanted to talk about her husband: his awkward art and fondness for annoying pets.

She wanted to talk about everything but his death.

Shelii sat on the narrow bench, stared out into silent space and waited for her shuttle.

She heard something: a mechanical whisper followed by three clicks. Shelii noticed an elegant tripod at the opposite end of the small shuttle stop. The tripod carried a glass cylinder of pink gel. A black, serpentine creature with a mouth at each extremity hung suspended in that gel.

"I startled you," came a monotone, synthetic voice.

"You did," Shelii confirmed. She tried to ignore her companion, but Shelii was never one to keep silent company. "Are you travelling to Earth as well?" she asked.

"Sadly, no." The tripod took a few steps towards her. "I am returning home."

"And where is that?"

A pause and then: "THREE."

Shelii gasped. She glanced at the hatch and searched space for signs of her shuttle but saw only stars. With a nervous sigh, she said: "So I'm trapped in a bubble with a predatory parasite. You are a clever hunter."

"You have nothing to worry about from me."

Shelii frowned. She fought the urge to scoot away from the tripod. "I suppose I'm too old for you?"

"Not at all, but we would both be required to fill out the proper paperwork. Then come integration procedures, and I suspect we would need to go through a batch of menopause-reversal treatments. Only then can

I attach." The parasite paused and added: "We are desperate for hosts, but I'll admit to some irony that we have yet to streamline this whole process."

Shelii winced and attempted to change the subject. "How long have you been away from THREE?"

"Not long. I had a line on a potential host, but it didn't work out."

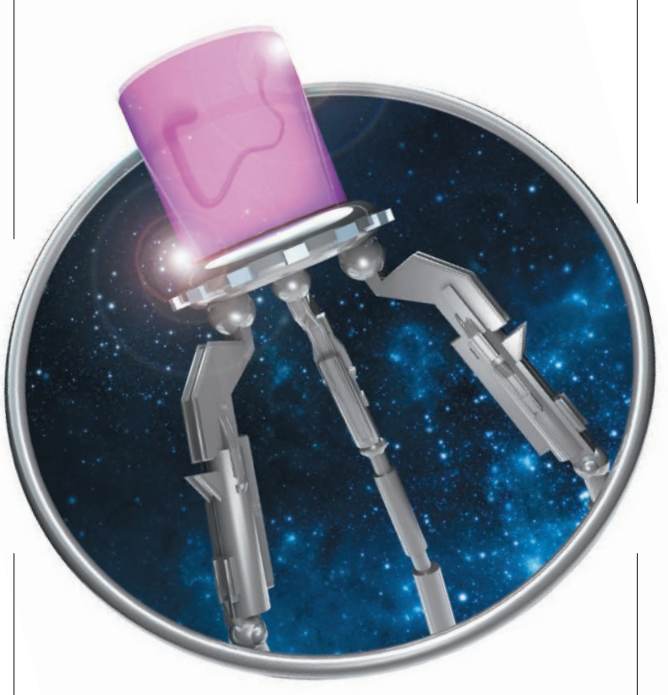

"But Caldera seems so far away."

"I am nearing the end and growing desperate. I received a relay about a boy with a terminal illness. My enzymes would have renewed his body, but his parents had second thoughts and sent me away. I understood their concern, but I wasted a lot of time filling out the forms required just to enter Xevilious. He would have lived for more than a thousand years and had a full life. By now, he is probably dead."

"Well, why not cure the boy and then detach yourself?"

"I cannot detach myself until I have laid and fertilized my eggs. If I tried, both the host and I would die. When you join with the Parasite-S, you must remain with the S."

"But you kill the host eventually? No matter what?"

"I must eventually reproduce. The host becomes a vessel for my offspring. I admit that the whole process must seem disgusting."

"Most sex is, I suppose. How much time do you have left?"

$\rightarrow$ NATURE.COM

Follow Futures: @NatureFutures f go.nature.com/mtoodm
"Not long."

Shelii felt an uncomfortable kinship with the creature.
They were both heading home just as age prepared to get the better of them.

"Earth is your home?" the parasite asked.

"Yes. I'll be living with my sisters. Once I have apologized for a few things, that is." She paused and traced a series of stars with her eyes. "I haven't been home in over 60 years." A thought occurred to her. She chuckled. "Can you make me young again?"

"Between my enzymes and our treatments, you would be renewed." The parasite paused, stepped closer, and added: "I promise you a long, experiential life."

Shelii sighed. She turned back to the stars and let her words wander. "I came to Caldera, because I wanted experiences. That was - oh my - 20 years after First Contact. It seemed like not much had changed on Earth. Grow up. Go to school. Get married. Have kids. Get old. Die. Out there were new worlds; unusual people; fascinating sexual ethics; surprising visions of beauty."

She began flipping through pages in her notebook and found a sketch of her worion husband.

She held up the notebook. "Can you see?"

"Heat signatures only."

"Oh ..." She closed the notebook and added: "You say that you can make me young. What I really need is for someone to bring me back. To the beginning. So that I can live it all again."

"There are new loves to be had."

Shelii considered this. She shook her head. "Not for me, I think. Not anymore."

"I understand. You can't fault me for trying."

Shelii smiled at the parasite and said nothing.

A few moments later, she noticed a flash out of the corner of her eye. A shuttle came alongside the bubble and docked.

"I believe this is mine," the parasite said as the hatch whirled open.

"Best of luck," Shelii said. The words embarrassed her.

"I wish you and your sisters the best," the parasite said before climbing on board. Moments later, the shuttle detached and drifted away from the bubble. Shelii watched it heel to port and accelerate along Caldera's arc before ascending into open space.

Hers would be along soon. -

Jeremy M. Gottwig is a former NASA librarian and programmer. He lives in Baltimore, Maryland, with his wife and youngson. 